\title{
"Iglesia me Llamo": Church Asylum and the Law in Spain and Colonial Spanish America
}

\author{
VICTOR M. URIBE-URAN \\ Florida International University
}

"Iglesia me llamo" ("church is my name") was the only phrase uttered over and over by numerous criminals during judicial interrogations that took place at various times throughout the Iberian kingdoms that ultimately became Spain, and their American colonies. ${ }^{1}$ This expression meant that even after committing heinous crimes, those outlaws received shelter at local churches and thereby felt entitled not to disclose any information to justice officials about their conduct. Such criminals were confident that it would not be easy to remove them from the church for punishment. Indeed, groups of wrongdoers turned churchyards, churches, their cloisters, and their adjoining cemeteries into permanent residences. They were alleged to move freely in and out of church buildings under cover of night and to bring friends, lovers, and liquor in for enjoyment. Their presence terrorized neighbors and passersby, and inconvenienced priests and parishioners alike.

The church and the crown, nevertheless, generally upheld the criminals' privilege to be sheltered and spared major punishment. All parties agreed that even if the culprits were proven guilty, neither the death sentence nor severe physical punishment could be imposed on them. This special protection persisted for more than twelve centuries. Most of the available historiography deals with England, where, as in other European countries for which research exists, the institution decayed centuries before the Spanish monarchs moved to curtail

\footnotetext{
1 Examples of the utterance can be found in literary and judicial narratives. See, for instance, the seventeenth-century Spanish novel by Diego Duque de Estrada, Comentarios del desengañado de si mismo, vida del mismo autor, Edition, introduction, and notes by Henry Ettinghausen (Madrid: Clásicos Castalia, 1982 [c. 1640s.]), 156-61. Several judicial cases in early eighteenth-century Cádiz also contain evidence of it. They are cited in the excellent study by Arturo Morgado García, Derecho de asilo y delincuencia en la diocesis de Cádiz (Cádiz: Diputación Provincial, 1991), 33, 38. There are frequent references in colonial Mexico's judicial cases from the late eighteenth century; see Archivo General de Indias (hereafter AGI), Guadalajara, 158; AGI, Guadalajara, 402.
} 
its advantages. ${ }^{2}$ For the Spanish Kingdoms in Iberia and their American colonies, little academic research of substance has been published on this intriguing subject. ${ }^{3}$ This article aims to begin to fill that gap.

After tracing the widespread presence of asylum in Spanish law, literature, and legal doctrine, this essay reviews a number of practical examples from criminal cases in various regions throughout Spanish America, particularly Panama, Mexico, and Cuba. The examples demonstrate the controversies that resulted from alleged excesses by both clergymen and criminals. Despite the intense debates between church and state authorities and various attempts at reform, the practice lingered on, as attested by the continuing attention from legal experts and crown authorities well into the nineteenth century. This makes the Spanish experience comparable perhaps only to that of Italy, and remarkably different from the period's other Western European kingdoms, even deeply Catholic monarchies like France.

\footnotetext{
2 There is also relatively abundant research on France, where, just as in England, the institution was weakened much earlier than in the Iberian realms. Most works, though, refer to the institution's earliest years. See, among others, F. Martroye, "L'asile et la legislation imperiale du IVe au VIe siècle," Memoires de la Société des Antiquaires de France 5 (Paris, 1919): 159-260; E. Reale, Le droit d'asile (Paris: Sirey, 1938); Pierre Timbal-Duclaux de Martin, Le droit d'asile (Paris: Librairie du Recueil Sirey, 1939); Leopold Koziebrodzki, "Le droit d'asile," Unpublished Thèse pour le Doctorat du Droit, Université de Paris, 1956; P. D. Caron, "Asile et Hospitalité dans le droit de l'Eglise Primitive," Revue Internationale des Droits de l'Antiquité, 10 (1963): 187-97; Jeannine Crosse-Durlin, "Le droit d'asile a Valenciennes aux XIVe et XVe siècles d'après les listes d'entrée en franchise," Revue du Nord 67, 267 (1985): 905-21; Michel Fixot and Elisabeth Zadora-Rio, "Introduction. La topographie des lieux d'asile dans les campagnes médiévales," in Fixot and Zadora-Rios eds., L'église, le terroir (Paris: Editions du CNRS, 1989), 11-19; Anne Ducloux, "La violation du droit d'asile par 'dol' en Gaule, au VIe siècle," Antiquité Tardive, 1 (1993): 207-19; idem., Ad ecclesiam Confugere. Naissance du droit d'asile dans les eglises (IVe- milieu du Ve. S.) (Paris: De Boccard, 1994).

${ }^{3}$ Unlike the relatively abundant literature on diplomatic and political asylum, the only available academic works on church asylum, to my knowledge, are the following, some of which touch on the subject marginally, anecdotally, or by merely reproducing and glossing over original documents on the theme. Florencio Porpeta, El derecho de asilo eclesiastico en España (Madrid, 1922); Elizabeth Howard West, "The Right of Asylum in New Mexico in the Seventeenth and Eighteenth Centuries," Hispanic American Historical Review 8 (1928): 357-91; also republished in New Mexico Historical Review 41 (Apr. 1966): 115-53; Tomás de Aquino García y García, El derecho de asilo en Indias (Madrid: Editorial Reus, 1930); Mario del Valle Muñóz, El derecho de asilo eclesiástico en el reino de Chile (Santiago: Biblioteca de la Univ. Católica, 1952); Rafael Serra Ruíz, El derecho de asilo en los castillos fronterizos de la reconquista (Murcia: Patronato de Cultura, 1965); Rafael Olaechea, "Anotaciones sobre la inmunidad local en el siglo XVIII español," Miscelanea Comillas 46 (July-Dec. 1966), 296-381, esp. 315-64; Jorge Comadrán Ruíz, "Algunas notas sobre el derecho de asilo eclesiástico y la jurisdicción civil y canónica. Dos dictamenes de mediados del siglo XVIII," Revista del Instituto de Historia del Derecho Ricardo Levene 22 (1971): 236-48; Abelardo Levaggi, "Las instituciones de clemencia en el derecho penal rioplatense," Revista de la Facultad de Derecho de México 26: 101-2 (Enero-June 1976), 243-97, esp. 276-86; Morgado García, Derecho de asilo y delincuencia; José María Ortuño Sánchez Pedreño, "El derecho de asilo en iglesias y sus cementerios en la legislación de Partidas," Glossae. Revista de Historia del Derecho Europeo 5-6 (1993-1994): 187-93.
} 


\section{GENERAL BACKGROUND AND COMPARATIVE CONTEXT}

Clerical and regalista (royalist) authors argued about whether the sanctuary originated as a gift from God or a secular custom. ${ }^{4}$ Ecclesiastical and civil authorities continued the debate until the nineteenth century. ${ }^{5}$ In any case, religious asylum in Christian temples was an important defense for criminals from the early days of Christendom. Constantine (ca. 274-337 A.D.) recognized sanctuary; so did Theodosius (346-395 A.D.) and other fourth-century Roman emperors. ${ }^{6}$ In regions of what later would be France, asylum was introduced by the sixth century A.D., ${ }^{7}$ and the institution was also present in England during the sixth and seventh centuries A.D. It was included in laws enacted in some Iberian kingdoms as early as 610 A.D., and became subject of regulation by church councils; among others, the ones of Toledo in 633, 638, and 681 A.D. ${ }^{8}$ Asylum was accepted in Germanic laws of the seventh century, in particular the Visigothic Liber Judiciorum (Book of the judges). ${ }^{9}$ The Byzantine Empire witnessed a debate during the eleventh century over the expansion of asylum to those who killed deliberately, which suggests that

\footnotetext{
${ }^{4}$ For a well-documented, contemporary practical manual and history written from a royalist perspective, see Fernando González de Socueba, Instrucción Manual para la más breve expedición de los casos prácticos y disputas de immunidad local. Noticia histórica de su origen, progresos y estado (Sevilla: Imprenta del Doctor Don Gerónymo de Castilla, 1766).

${ }_{5}^{5}$ In 1864, asserting that it formed part of the ius divinum, one of Pope Pius IX's Syllabus of Errors condemned the view that ecclesiastical immunity was civil in origin. See R. H. Helmholz, "The Law of Sanctuary," in idem., The Ius Commune in England (Oxford: Oxford University Press, 2001), 16-80, esp. 18.

${ }^{6}$ Among the Greeks and especially among the Romans, temples, altars, and statues of the emperor were places of refuge. Thus, when Christianity became the religion of the state, the emperor extended the right of sanctuary to the churches. Authoritative discussions of the origin of asylum among the Hebrews and also in Greece and Rome can be found in Timbal-Duclaux de Martin, Le droit d'asile, Pt. 1; Ken J. Rigsby, Asylia: Territorial Inviolability in the Hellenistic World (Berkeley: University of California Press, 1996); Charles de Beaurepaire, "Essai sur l'asile Religieux dans l'Empire Romain et la Monarchie Francaise," Bibliotheque de l'Ecole de Chartes 14 (1853): 351-75; 15 (1853): 151-75, 341-59; Anne Ducloux, "L'Eglise, l'asile et l'aide aux condamnés d'apres la constitution du 27 juillet 398," in Revue d'Histoire du Droit Français et Etranger 69 (1991): 141-76; Norman Maclaren Trenholme, "The Right of Sanctuary in England. A Study in Institutional History," University of Missouri Studies 1, 5 (1903): 1-106, esp. 4-9; Luis Redonet y López-Doriga, "Nacimiento del derecho de asilo," Discursos Leidos ante la Real Academia de la Historia (Madrid: Imprenta Viuda e Hijos de Jaime Rates, 1928), 10-88; and Gab. Le Bas, "Asile," Dictionnaire d'histoire et de Géographie Ecclésiastiques, vol. 4 (1912), 1036-48. Its origin in Christian churches is discussed by Ducloux, Ad ecclesiam confugere, 5-25, passim. For a discussion of some of the Roman laws on the subject, see Timbal Duclaux de Martin, Le droit d'asile, 77, 119, 135; Fixot and Zadora-Rio, L'église, le terroir, 11.

${ }^{7}$ See L. R. Misserey, “Asile en Occident," Dictionnaire de Droit Canonique 1 (1935): 1089104, esp. 1090.

${ }^{8}$ For its presence in King Gundemaro's 610 law and in seventh-century church councils, see the well-documented study by Olaechea, "Anotaciones sobre la inmunidad local," 324.

${ }^{9}$ After its Spanish translation and adoption by Spanish King Alphonse X in 1254, this came to be known as the Fuero Juzgo. See Laws 1 to 4, title 1, libro 10, Fuero Juzgo, in Códigos españoles concordados y anotados, 12 vols. (Madrid: Imprenta de la Publicidad, a cargo de M. Rivadeneyra, 1847-1851), 1: 179.
} 
the practice had been well established much earlier in Byzantium for other types of crimes. ${ }^{10}$

By the thirteenth century, religious asylum had thus become a central institution in canon law, the "universal" law of the Catholic Church. It was, for instance, addressed in some of the first canon law compilations, particularly Pope Innocent III's Compilatio quarta issued in 1216, and Gregory IX's Decretals of 1234, in which one chapter (Cap. 9. and feq. de Immunit. Ecclef.) dealt with asylum under the heading of immunity (immunitate ecclesiae), as sanctuary also became widely accepted. By this time, it was already clear that without ecclesiastical authorization, civil justice officials could not remove criminals who found shelter in a Catholic church. Excluded from the privilege were but a few crimes; brigandage or banditry commonly, and also murders committed in a church or cemetery. Whenever it was granted, authorization was issued with the promise that criminals would not be sentenced to death or corporal punishment (poena aflicitiva corporis). ${ }^{11}$

Though chronologically short compared with the Iberian case, the English experience is arguably the richest, and has drawn the most academic attention. In England, the privilege of sanctuary seems to have begun around the time of the Christianization of the region in the late sixth century A.D., and was clearly part of seventh- and tenth-century bodies of law. ${ }^{12}$ It "settled into a regular form," becoming widely familiar there and also in neighboring Scotland and Wales, during the twelfth and thirteenth centuries. The practice survived until its alleged demise during the Reformation, starting under Henry VIII in the seventeenth century. ${ }^{13}$

Relying on a rich body of evidence, including classical texts, legal treatises, royal court records, literary works, ancient ballads and lyrics, contemporary historical narratives, Church registers, and other sources, scholars of sanctuary in England have addressed a host of traditional institutional issues: the institution's early origins and meaning, whether it reflected the privileges of the church, and the relative significance of Church law compared to secular legislation in shaping it. Other researchers have looked at locations and regional case studies of church and secular sanctuaries. Historians have explored more innovative topics, including particularly significant and colorful modalities of sanctuary, especially the one for insolvent debtors; the social attitudes toward asylum; the involvement of local communities in its functioning; the

\footnotetext{
${ }^{10}$ Ruth J. Macrides, "Killing, Asylum and the Law in Bizantium," Speculum 63 (1988): 50938. See also E. Herman, "Asile Dans 1'Eglise Oriental," in Dictionnaire de Droit Canonique, 1 (1935): 1084-89.

11 González de Socueba, Instrucción Manual, 92-95; Timbal-Duclaux de Martin, Le droit d'asile, 150-51.

${ }^{12}$ It appears in the 680 A.D. Laws of Ine, King of Wessex (688-725), and in the Laws of King Edgar (c. 962). See Threnholme, "Right of Sanctuary," 12-14.

13 Helmholz, "Law of Sanctuary," 18.
} 
rise of the secular state's actual impact on it; and the true extent of its decline and ultimate abolition. ${ }^{14}$

The field has even generated historiographical contention. In a recent work, R. H. Helmholz challenges the dominant interpretation that the English law of sanctuary was purely "secular" while asserting the significance of canon law. At the same time, Helmholz reinterprets the abolition of sanctuary. In his view, this was not a simple victory of English common law over church law, as many scholars have claimed, but the absorption of the latter by the former. ${ }^{15}$ Similarly, Andre Reville challenges the longstanding view that the operation of sanctuary in England throughout time has depended fundamentally on whether church or state authorities controlled it. He argues that the functioning of asylum depended "first and foremost, upon the involvement of the local community."16 Sanctuary, and the abjuration that accompanied it, were a means to resolve tensions and facilitate the settlement of disputes within communities, and also a mechanism of local relief from excesses of government. $^{17}$

While the arguments over sanctuary in Britain might offer a general guide for other countries, the paucity of primary investigation regarding Spanish Iberia and its American colonies precludes specific academic debates. Instead, this study broaches foundational issues, including the institution's basic legal background and mechanics and some aspects of its general evolution and reform. At the same time, while indicative of regular and heated disputes between crown and church, the institution's comparatively long duration speaks about the lasting dominance of the Catholic Church in all realms of Spanish life into late colonial times (education, health care, taxation, economic production, record-keeping, and so on). This study also sheds light on the factors leading to the reform of asylum, clerical excesses being one of them. At the same time, this essay establishes that the history of sanctuary clearly reflects the

14 The bibliography is just too vast to cite here entirely. Some of the classic works on the subject are by Trenholme, "Right of Sanctuary"; Rev. J. Charles Cox, The Sanctuaries and Sanctuary Seekers of Medieval England (London: George Allen and Sons, 1911); and Isobel Thornley, "The Destruction of Sanctuary," in, R. W. Seton-Watson, ed., Tudor Studies (London and New York: Longmans, Green and Co, 1924), 182-207. For some recent works that rely on and list many key studies on the subject and related reference works, see also Gervase Rosier, "Sanctuary and Social Negotiation in Medieval England," in, John Blair and Brian Golding, eds., The Cloister and the World: Essays in Medieval History in Honour of Barbara Harvey (Oxford: Clarendon Press, 1996), 57-79; Nigel Stirk, "Arresting Ambiguity: the Shifting Geographies of a London Debtors' Sanctuary in the Eighteenth Century," Social History 25, 3 (Oct. 2000): 316-29; and Helmholz, "Law of Sanctuary," passim. An informative discussion of some legal dimensions can be found in Charles H. Riggs Jr., Criminal Asylum in Anglo-Saxon Law (Gainesville: University of Florida Monographs, 1963).

15 See Helmholz, "Law of Sanctuary," passim.

16 See Andre Reville, “L'Abjuratio Regni. Histoire d'une Institution Anglaise,” Revue Historique 50 (1892): $1-42$.

17 The abjuration (or "abjuration of the realm") was an oath by the criminal under sanctuary to leave the country, never to return. Rosser, "Sanctuary and Social Negotiation," 60, 63, 75, passim. 
fact that criminals, who came from all walks of life-corrupt bureaucrats, abusive noblemen, quarreling common soldiers, and rustic accidental killers as well as professional thieves, cold-blooded murderers, and violent spouses alike-incurred excesses of their own. In the process, I shall highlight the resourcefulness and day-to-day life of offenders under sanctuary. The criminals' casual approach to life in churches offering them shelter, and their penchant for scandal, were a significant factor contributing to the institution's alleged decline.

CHURCH ASYLUM IN SPANISH LAW, LITERATURE, AND LEGAL DOCTRINE

The institution of sanctuary was part of civil laws and religious canons of the seventh century, and is found in several local fueros (municipal charters with privileges) from the ninth century. Compilations of civil legislation in the Iberian Peninsula clearly recognized the institution of sanctuary in medieval times. ${ }^{18}$ Not only the Fuero Juzgo (1254), but also the Fuero Real (1256), the Siete Partidas (1251-1265), and the Ordenanzas Reales de Castilla (also known as Ordenamiento Real or Ordenamiento de Montalvo, 1484) all contained provisions protecting murderers, thieves, debtors, and other criminals seeking refuge in Catholic churches and related places. The Fuero Real, for instance, provided that whoever broke into a church or cemetery for the sake of extracting a refugee from it would commit sacrilege. It legitimated shelter given to criminals, except for publicly known robbers; those who at night had destroyed vineyards, trees, and property markers (mojones de heredades); and anyone who committed murder inside a church or cemetery. ${ }^{19}$

The Siete Partidas established that debtors and other "wrongdoers" could not be expelled from churches where they had sought refuge, nor could they be killed or subjected to any bodily chastisement (dalle pena en el cuerpo ninguna). Whoever wished to extract them from their shelter should provide a caución, or security bond, supported by a bondsman or, if unable to do so, swear an oath under God that, once extracted, the culprits would not suffer any bodily harm (mal ninguno en el cuerpo). This also applied to serfs who ran away from their masters and entered churches. The Siete Partidas also excluded from the benefit of asylum traitors, rapists of virgins, forgers, and royal-tax evaders. Such exceptions suggest the particular gravity attributed to these offenses at the time. ${ }^{20}$

\footnotetext{
18 On local fueros, see Serra Ruiz, El derecho de asilo en los castillos fronterizos, 29-46, passim.

19 See laws 7 and 8, title 5, libro 1; and law 15, title 20, libro 3, Fuero Real, both in Códigos españoles 1: $353-401$.

${ }^{20}$ See laws 1 to 5, title 11, partida 1, in Códigos españoles, 2: 210-15; Ortuño Sánchez Pedreño, "El derecho de asilo en iglesias y sus cementerios," 187-93.
} 
The Ordenanzas Reales de Castilla made special reference to the need to limit the seemingly too liberal asylum being granted to adulterous women, robbers, perfidious murderers, and others flocking to the locality of Valdezcaray, east of Burgos in northern Spain. Over time, perhaps because it was a señorio (manor) and therefore subject to seigneurial justice, as opposed to royal justice, this area had become the center for all sorts of Spanish criminals seeking shelter. ${ }^{21}$ The Nueva Recopilación, issued in 1567 and revised and edited various times thereafter until the late eighteenth century, also contained several provisions about ecclesiastical immunity, strikingly similar in nature to those of the Fuero Real. ${ }^{22}$ Throughout the seventeenth and eighteenth centuries, such legislation applied to numerous asylum cases in Iberia. Under such regulations in the region of Cádiz, for example, more than 785 people claimed asylum during that time. ${ }^{23}$

In Spain's overseas possessions, justice officials considered cases of immunity from the earliest days of the conquest; asylum was instituted from the moment Europeans arrived in the new territories. One of the earliest chroniclers of the conquest, Gonzalo Fernández de Oviedo (1478-1557), author of the monumental Historia general y natural de las Indias, published in Seville between 1535 and 1537, gives examples of asylum in the 1520s. He had witnessed and participated in the exploration and conquest of several territories of tierra firme (mainland) in the company of the explorer Pedro Arias de Avila, better known as the infamous Pedrarias. They explored and settled parts of what later became Panama and Nicaragua.

Because González de Oviedo served as veedor, or auditor, in charge of monitoring the actions and reporting the misdeeds of some of the royal officials, and was also in charge of administering justice at the local level, he attracted animosity. Once, in about 1523, as he was strolling past a church with the alcalde mayor (local magistrate), one of his adversaries, Simón Bernal, stabbed him severely in the head and face. The aggressor ran away and, rather than taking refuge in the church near where the incident occurred, from which he might be extracted, rapidly fled to the iglesia mayor (cathedral church), where the parish priest and other clergymen sheltered him. ${ }^{24}$

By 1569, King Phillip II had already issued provisions asking that ecclesiastical immunity be preserved in the colonies and that justice officials refrain

21 Law 6, title 2, libro 1, Ordenanzas Reales de Castilla por las cuales primeramente se han de librar todos los pleitos civiles y criminales (Toledo: En casa de Juan de Ayala, 1549), ii. See also Socueba, Instrucción Manual, 97-100.

22 Laws 1 to 3, title 2, libro 1, Recopilación de leyes de estos reynos, 1: 5.

23 See Morgado García, Derecho de asilo y delincuencia, 62-65.

24 Gonzalo Fernández de Oviedo, Historia General y Natural de las Indias, 5 vols. (Madrid: Biblioteca de Autores Espanoles, 1959), 3: 277 [corresponds to book 9, 2d part, ch. 17 of the original edition]. 
from breaking into churches and extracting criminals sheltered within. ${ }^{25}$ This must have benefited Catalina de Erauso (1585-1650), one of the extraordinary characters of the colonial era, who gained notoriety as "la Monja Alférez" (the lieutenant nun). During her time in the New World she was under asylum at least half a dozen times. Born in San Sebastián de Guipúzcoa and raised in a convent, she fled the cloister in 1600 after a fight with another nun, without taking final vows. Later, dressing as a man, she left for the New World. In Saña, Peru, she sought sanctuary for the first time after stabbing a man. Shortly thereafter, in the city of Trujillo, she killed a man and sought shelter in the local cathedral, still disguised as a man herself. She escaped to Lima and enlisted in the army sent to put down the Araucano Indian uprising in Chile. There she indulged in a legendary brawl in Concepción, where she killed both an opponent and the justice official who attempted to arrest her. Once more she sought sanctuary, at the Convent of San Francisco. During a nighttime escapade outside the monastery, she participated as a second in a midnight duel in which she unknowingly injured her own brother, Captain Miguel de Erauso, in whose regiment she had recently served. From her sanctuary, Catalina witnessed her brother's corpse being laid to rest in the convent's cemetery.

She spent more than eight months at the San Francisco convent until she fled because of more brawling. After many other intervening adventures, she found herself once more sheltered at another Franciscan monastery in the city of La Plata. This time she hid from the law after having killed a man in a street fight. Abandoning sanctuary a fourth time, she stabbed a man to death in Cuzco and sought refuge at the Church of San Francisco. Her amazing life confirms, if nothing else, how convents and monasteries in colonial Spanish America actively protected all kinds of criminals. ${ }^{26}$

Even though monasteries were admonished not to give shelter to criminals whose particular offenses were excluded from immunity or to impede the removal of those criminals by royal justice officials, the 1681 Recopilación de las Indias fully recognized ecclesiastical immunity. It ordered viceroys, governors, audiencias (courts of appeal), and justice officials in general to respect the canon law, the decisions of diocesan synods, and ecclesiastical pronouncement over cases tried by ecclesiastical courts (which, in the Americas as in Spain, had jurisdiction over a variety of persons and legal issues). It warned them not to introduce any innovation, even when dealing with atrocious crimes. ${ }^{27}$

25 This provision was later incorporated into the Recopilación de las Leyes de Indias. See title 5 , book 1. See, for instance, another incident being tried in Mariquita, central New Granada (today's Colombia) in 1603. Archivo General de la Nación (hereafter AGN), Bogotá, Ciminales, 25, D. 15.

${ }^{26}$ Catalina de Erauso, Lieutenant Nun: Memoir of a Basque Transvestite in the New World. Catalina de Erauso. Michele Stepto and Gabriel Stepto, trans from Spanish; foreword by Marjorie Garber, (Boston: Beacon Press, 1996), 3, 11, 14-15, 22-25, 45-47, 55-57.

${ }^{27}$ See all the laws in title 5, book 1, Recopilación de las Leyes de Indias; García y García, El derecho de asilo en Indias, 35-40. 
Being such an old, well-established, somewhat dramatic, and frequently invoked legal mechanism on both sides of the Atlantic, sanctuary became a subject of literary commentaries by several Spanish authors from the 1550s through the seventeenth century. Though literary narratives might not be purely true, they suggest the widespread practice of sanctuary in different cities of the kingdom, including Madrid, Toledo, and, most prominently, the southern city of Seville, which was the mercantile and bureaucratic hub, departure gate, and port of entry to and from the American colonies. The texts also mention the latter as asylum havens.

One of the earliest and most celebrated picaresque and satirical Iberian novels, the anonymous Lazarillo de Tormes (1554), set in the city of Toledo, denounces clerical abuses, offers snapshots of the wretched conditions of material life in Iberia at the time, and also touches on sanctuary. Among other references to typical folk in contemporary society (retired soldiers, beggars, escuderos or servants, and the like), the book alludes to an incident involving the participation of retraidos, an expression used to designate alleged criminals under sanctuary in a local church. ${ }^{28}$ The novel's protagonist, servant Lázaro de Tormes, and his master (amo), an alguacil or justice official, are chased one night by a group of such retraidos, who hurl stones while the two run for their lives. ${ }^{29}$

Subsequent Spanish Golden Age authors, such as the famous Miguel de Cervantes Saavedra (1547-1616) and Francisco de Quevedo (1580-1645), and the lesser known but truly remarkable Vicente Espinel (1550-1624) and Diego Duque de Estrada (c. 1589-?), also included episodes in which places and seekers of sanctuary were common. Cervantes's El celoso extremeño, a piece within his larger Novelas ejemplares (1613), describes the Indies as the refuge and safe heaven of desperate Spaniards, a paradise for murderers, and an iglesia de los alzados, a sanctuary of insolvent debtors. ${ }^{30}$ Quevedo's short piece "Capitulaciones de la corte y oficios entretenidos en ella," an early seventeenth-century description of some of the most contemptible denizens of the court at Madrid, includes a section on rufianes de embeleco, or petty ruffians, who, after taking women's money, go antana, a term given to the

\footnotetext{
28 Juan de Hevia Bolaños, Curia philipica: Laberintho de comercio terrestre y naval: Distribuido en tres libros (Lima, Perú Revista Peruana de Derecho de la Empresa, 1988 [1602]), III Parte, par. 12, retraidos.

29 Finding his master's occupation to be somewhat dangerous, Lázaro decides to leave his service and finds a job as the town crier (pregonero). See La vida de Lazarillo de Tormes y de sus fortunas y adversidades, Everett W. Hesse and Harry F. Williams, eds.; introduction by Americo Castro (Madison: University of Wisconsin Press, 1969), 55.

30 See Miguel de Cervantes, El Viejo celoso and El celoso Extremeño, edited with introduction, notes, and bibliography by Paul Lewis-Smith (London: Bristol Classical Press, 2001), 19, 46. Cervantes' references to churches as providers of sanctuary can also be found in his novel Rinconete and Cortadillo. See Miguel de Cervantes Saavedra, Rinconete y Cortadillo. Edición crítica por Francisco Rodríguez Marín (Madrid: Revista de Archivos Bibliotecas y Museos, 1920), 115-16.
} 
customary practice of seeking refuge in a local church (que así llaman ellos ponerse en la iglesia). ${ }^{31}$

Quevedo's Vida del buscón llamado don Pablos (1626), one of the three most celebrated picaresque novels of its time, depicts a hustler and pillo (small thief) who recounts how his father, a barber and occasional common thief, "hung out in churches, and not precisely because he was a good Christian" (andaba por las iglesias, y no de puro buen cristiano). ${ }^{32}$ That model of a father told his son he had never confessed a crime unless ordered to do so by the one who provided him sanctuary, la Santa Madre Iglesia. ${ }^{33}$ Eventually, Don Pablos himself seeks sanctuary. In Seville, on his way to America, he falls in with ruffians, kills some guards, and immediately seeks refuge in the local cathedral ("nos acogimos a la Iglesia Mayor"). Not only do they escape thus the rigor de la justicia (justice's rigor), but they also manage to have a great time in the process. With other retraidos, they arranged to smuggle prostitutes inside, and also find amusement by playing musical instruments and learning folksongs from one another. Despite the close watch of justice officials posted around the church, they disguise themselves and manage to get in and out of sanctuary after midnight. ${ }^{34}$ Judging by this and other literary narratives of the period, it appears that the anxious petition filed to the king in the midsixteenth century by Diego Martínez, a resident of Seville, for the immediate extraction of the numerous retraidos sheltered in the city's local churches did not come to fruition. ${ }^{35}$

In a similar vein, Vicente Espinel's autobiographical novel Vida de Marcos Obregón (1618) describes its protagonist's exploits as he serves under different masters in various places throughout Spain. In one episode, Obregón, who, like Lázaro de Tormes, is an escudero, or servant, is strolling Madrid at night. To avoid being taken for a retraido out of his sanctuary, he stops at a tomb at the center of a plaza and holds a rosary, pretending to pray as the guards patrolling the place try to arrest him. ${ }^{36}$ In another scene, in Seville, he picks a fight with a retraido from the Corral de los Naranjos, the same part of the cathedral in which Quevedo's Don Pablos sought shelter after one of his fights. ${ }^{37}$

Another reference to sanctuary is found in the Duque de Estrada's seemingly autobiographical novel Comentarios del desengañado de sí mismo, written in

\footnotetext{
31 See Francisco de Quevedo Villegas, Obras Completas (Madrid: Ediciones Atlas, 1946), in Biblioteca de Autores Españoles 1: 465-66.

32 The two other fundamental Spanish picaresque works are Lazarillo de Tormes and Guzmán de Alfarache (Part I, 1599; Part II, 1604), by Mateo Alemán.

33 Francisco Quevedo, La vida del buscón llamado don Pablos, edited with introduction and notes by James Iffland (Newark: Juan de la Cuesta, 1988), 9.

34 Quevedo, La vida del buscón, 175-76.

35 AGI, Indiferente, 424, Legajo 21, fol. 260v.

36 Espinel, Vida de Marcos Obregón, 2 vols. Edición, prólogo y notas de Samuel Gili Gaya (Madrid: Espasa-Calpe, 1970), 1: 21.

37 Ibid., 2: 20-22.
} 
the 1640s but first published only in 1860 . He commits murder in Toledo, and justice officials search for him in various hideouts, including churches, where they are certain they will find him seeking protection; he flees to Seville instead. ${ }^{38}$ After a street brawl, Duque de Estrada, too, seeks refuge in the Corral de los Naranjos. His references to this place are quite similar to those in Quevedo's Vida del buscón. He presents it as the hangout of low-life characters of all sorts, prostitutes, deserters, and gamblers in particular, and the scene of frequent fights among its occasional occupants. While in the sanctuary, the protagonist himself stabs another man in a fight over a woman. ${ }^{39}$

Forced to flee, Duque de Estrada ultimately returns to his native Toledo. As the local chief justice (corregidor) attempts to have him arrested, he takes sanctuary in Toledo's iglesia mayor. After a month in the church's tower, he resolves to leave and visit his anguished parents, but promptly returns to the tower, which the corregidor sends soldiers to search. Although he is promised that his sanctuary will be upheld (valdria la iglesia), he refuses to turn himself in, remembering the canon laws protecting asylum. A battle ensues, with Duque de Estrada throwing stones at the soldiers while they aim their guns at his place of refuge. Alerted by the scandal, the bishop and local clergy come to his rescue. They scold the soldiers, excommunicate the corregidor, and thus put an end to the siege. Days later, assisted by his family and some local officials opportunely bribed, Duque de Estrada manages to leave the tower for good, escaping to the city of Guadalajara. At one point, however, he mistakenly thinks that rather than being with family envoys, he has fallen into the corregidor's hands. His immediate reaction is to shout "iglesia me llamo," the customary way to invoke the right to religious asylum. As promised, his loyal companions soon escort him out of the city. ${ }^{40}$

These narratives illustrate how retraidos went in and out of sanctuaries almost at will. Apparently they were also easy to spot, and always appeared ready to pick fights and cause havoc. No wonder, then, that sanctuaries and retraidos appear so often in the period's novels. ${ }^{41}$ Historical evidence also indicates that these literary references and stories, including allusions to the church's prompt excommunication of state officials who challenged asylum, were far from embellished or exaggerated; it suggests that many of these passages imitated real life, exaggerated though they might have been in some ways.

Besides drawing literary interest, church asylum also engaged contemporary legal writers. Virtually every treatise on criminal law gave asylum detailed attention. Renowned sixteenth-century legal experts Antonio Gómez (1501-1562/1572),

38 See Duque de Estrada, Comentarios del desengañado de si mismo, 106.

39 Ibid., 109-10.

40 Ibid., 156-61.

41 Some biographical manuscripts of the time also brought up the subject. See Alonso de Contreras, Vida, nacimiento, padres y crianza del Capitán Alonso de Contreras, natural de Madrid... escrita por el mismo [c. 1630] (Madrid: Alianza Editorial, 1967), 8. 
Diego de Covarrubias y Leyva (1523-1577), Jerónimo Castillo de Bobadilla (1546/47-1605), and Juan de Hevia Bolaños (1570-1623) all discussed sanctuary in their important treatises or commentaries on Castilian law. Much in the manner of the Fuero Real, Gómez points out that public thieves, and those who at night destroyed crops, committed their crimes inside churches, or were guilty of treacherous homicides, were not covered by religious immunity. To this exclusion list he adds those who escaped from jail into a church. Covarrubias also reviews in detail the list of crimes excluded. Then he admonishes sternly that, following the French practice, while immunity cases are being discussed justice officials should proceed to the prompt extraction of criminals from churches. They must lock them up in safe jails to prevent ecclesiastical authorities from transferring them to another location, thus keeping them away from punishment, a seemingly customary practice.

Castillo de Bobadilla, a former corregidor who belonged to the Royal Council and was fiscal (crown attorney) of the Real Chancillería of Valladolid, points out that whenever justice officials wished to extract from churches any criminals who had sought refuge there, they would need ecclesiastical authorization, even in cases of crimes excluded from the benefit of immunity. He advises those secular judges who do have authorization to proceed discreetly and with extreme caution and deference. ${ }^{42}$ As for Hevia Bolaños, his widely used Curia Philippica of 1602 provides the most liberal interpretation of the institution. Asylum, he argues, can be obtained in all churches, even unconsecrated ones where Mass is not celebrated or those that have been demolished to be rebuilt. He extends the concept to include the nearby claustros, dormitorios, refectorios, huertas, hospitales, monasterios y cementerios (cloisters, dormitories, refectories, gardens, hospitals, monasteries, and cemeteries). Even criminals who are under excommunication or other forms of religious censure (suspensos and entredichos) can enjoy the benefit, he insists. Asylum should cover all sorts of crimes except the ones traditionally excluded. Hevia Bolaños also admonishes that the beneficiaries of sanctuary cannot be deprived of food, nor can guards surround the church. ${ }^{43}$

Well into the next century, this traditional legal institution and practice clearly remained central, and several more works of jurisprudence continued

\footnotetext{
42 See Antonio Gómez, Commentariorum Variarum que Resolutionum Iuris Civilis Communis \& Regij, Tomus Tertius and Ultimus. De Delictis. Autore Praeclaro Viro Antonio Gomezio (Salamanca, C. M. Typographi, 1569), 3: Cap. 10, 73-75, esp. 73v; Diego Covarrubia Leiva, Variarum ex Iure Pontificio, Regio, \& Caesareo Resolutionum (Salmanca: Andreas à Portonarijs, 1552), Liber II, cap. 20, 156v-64, esp. 164; and Jerónimo Castillo de Bobadilla, Política para corregidores y señores de vasallos en tiempos de paz y de Guerra (Madrid: Edición Facimil. Instituto de Estudios de Administración Local, 1978) [Basada en la edición de Amberes: Juan Bautista Verdussem, 1704], 1: 422-23, lib. 2, cap. 14, no. 93.

43 Hevia Bolaños, Curia Philipica, III Parte, par. 12, "retraidos."
} 
to elaborate on it. ${ }^{44}$ Discussing the history of asylum to highlight what he considered to be its secular origins, royalist author Fernando González de Socueba in 1766 gave a much narrower interpretation of its scope than the one proposed by Hevia Bolaños. He explains that asylum was originally intended to protect debtors, accidental murderers, and other petty criminals. He laments that over the years it has become a widespread practice, and celebrates how asylum is being restricted in England, Germany, Italy, and Portugal. $^{45}$

In 1796, in the sixth edition of his popular manual on criminal and civil law, Spanish jurist and magistrate Francisco Elizondo explains that religious asylum must be granted not only to those who have entered a church but also to those who, the church being closed, approached its doors, touched its walls, or entered the adjacent homes of priests. In the same vein as Hevia Bolaños, though with a few more restrictions, Elizondo even considers that criminals could seek asylum in remote ermitas (sic), pilgrimage altars or chapels, and in rural churches, as long as Mass was more or less regularly celebrated within. Like the rest, this author goes on to discuss the procedure required to extract criminals from such places. He also proposes resolutions to controversies between ecclesiastical and secular authorities, and stresses that judges who violate ecclesiastical immunity risk excommunication. ${ }^{46}$

The contradictory attitudes of jurists like González de Socueba and Elizondo mirrored even more intense disputes over the institution, particularly during the eighteenth century. During that time, in good part as a result of controversial practices in the New World, asylum fell routinely under the gaze of both ecclesiastical and royal officials who, though frequently at odds, nonetheless concurred in trying to significantly reform the privilege.

\section{PRIESTLY AND CRIMINAL EXCESSES}

Asylum-related conflicts between the church and the crown persisted well into the late colonial period. Indeed, such conflicts were perhaps more regular, protracted, and notorious than any other conflict involving both institutions. As a result, the eighteenth century became possibly the most intense period of discussing and revising the asylum rules and practices, especially in the New World. The quarrels, moreover, had a clear impact not only at the imperial level but also at the local one; they touched not just the upper echelons of society, but also the masses.

\footnotetext{
44 Between the sixteenth and eighteenth centuries, doctrinal commentaries continued to be published. See, for instance, Antonio de Aguilar Mendivil, Manifestación juridica sobre el derecho de inmunidad y sagrado de las iglesias y monasterios (Murcia: 1688).

45 González de Socueba, Instrucción manual, 4-5, 101-3, passim.

46 Francisco Elizondo, Práctica universal forense de los tribunales de España y de las Indias, 6th ed. (Madrid: En la Imprenta de Ramón Ruíz, 1796), 1: 284-89; 3: 317-34.
} 
The disputes mainly concerned the crimes covered by asylum provisions and the exact procedure in cases involving religious immunity, particularly how to extract criminals from churches to royal prisons while they were being tried. Related arguments concerned the excommunication of royal officials accused of having taken people out of sanctuary. Documented cases speak of the attitudes and tribulations of those involved in these disputes, especially the clergy, the royal officials, and the criminals themselves.

Archival records demonstrate that the clergy, confident of the church's prerogatives, frequently refused to cooperate with royal officials trying to extract asylum seekers, even when their crimes were allegedly excluded from the sanctuary benefit. In the late 1680s, for instance, two justices (oidores) from New Spain's Guadalajara Audiencia and a local alcalde were excommunicated. Disregarding the complaints of the ecclesiastical judge and his notary, they had extracted from the Santo Domingo convent one Pedro Raymundo, a mulatto who had recently stabbed an Indian woman to death, a brutal crime allegedly excluded from sanctuary. The royal officials subsequently failed to reveal that Raymundo had been sentenced to death and had been executed in the jail, further violating the laws of sanctuary. The civil authorities kept the corpse inside, and finally brought it out to display on the gallows only when notified that the church had reversed its excommunication order. $^{47}$

Another telling instance occurred in Zacatecas when a group of ten young bandits, including a mulatto, several Indians, a coyote (African and indigenous mixture), a castizo (mestizo and Spanish mixture), and at least one Spaniard, escaped from jail and found shelter in the church of the city's San Antonio convent. $^{48}$ At the beginning of 1709 , they had robbed several travelers and muleteers on their way to the mining camp of Fresnillo, in northern Mexico, and had killed at least one person in the process. The Zacatecas corregidor, the city's chief justice and main royal administrator, promptly extracted them from the convent, arguing, as the law provided, that their crimes were excluded from ecclesiastical immunity. He did so, however, without ecclesiastical authorization. Much as in the previous case, he sentenced several of them to death by hanging, even though throughout the trial they had uttered the customary iglesia me llamo in response to all questions. Furthermore, the corregidor ordered that their bodies be dismembered and, as a typical warning and deterrent for the public, the body parts be exhibited in different places, with the heads sent to Fresnillo. In consultation with the Guadalajara Audiencia, the

47 AGI, Guadalajara, 402.

48 AGI, Guadalajara, 158. On these and other ethno-racial categories in colonial Spanish America, see Susan Kellogg, "Depicting Mestizaje: Gendered Images of Ethnorace in Colonial Mexican Texts," Journal of Women's History 12, 3 (2000): 62-92; and R. Douglas Cope, The Limits of Racial Domination: Plebeian Society in Colonial Mexico City, 1660-1720 (Madison: University of Wisconsin Press, 1994). 
sentence was executed less than five months after the criminals were removed from the convent. Receiving notice of these events, the enraged local bishop immediately proceeded to excommunicate the corregidor, one of the local mayors, and two of the notaries who had participated in the proceedings. The ensuing dispute between the local royal and ecclesiastical officials reached the Spanish Council of the Indies the following year. ${ }^{49}$

Other disputes regularly resulted in the excommunication of royal functionaries, and even the indefinite suspension of masses (entredichos) for entire localities. This occurred in Panama in 1730, when the former president and captain general of the region, Don Manuel de Alderete, Mariscal de Campo and Knight of Santiago, sought asylum in the Church and Convent of Santo Domingo. Alderete had just undergone a residencia, an investigation and review of his term in office. His investigator and successor, the Marquis of Villahermosa, had found alleged irregularities. Alderete was about to be preemptively transferred from house arrest to a local prison fort. From there he would be sent back to Spain for further inquiries. Instead of obeying the order to go to the fort, he escaped from his house and sought refuge in the church. He immediately received support from the local bishop (with whom, we may presume, he had had a friendly relationship during his time in office).

Attempts by Villahermosa to have Alderete removed from the church building inevitably led to a major confrontation between the royal authorities and the ecclesiastical hierarchy. The latter also objected to the siege allegedly imposed by royal soldiers against the church, which obstructed parishioners' entry and prevented the priests from receiving their daily provisions. Consequently, the bishop excommunicated the new captain general, the crown's attorney, and various other state officials, and imposed an entredicho against the entire city, which prompted angry mobs to take to the streets in protest against the royal actions. The bishop also ordered a large group of priests to don solemn garments and, while carrying a large black cross, to conduct a public ritual (and show of force) in front of Villahermosa's residence, thereby formalizing the spiritual curse on the captain general and justifying the canonical censure. The case ultimately reached the Consejo de Indias, highest royal council for such matters, where both parties defended their actions and litigated the matter for more than a year. ${ }^{50}$

In other instances, the church protected influential members of local society even if they had seriously abused royal laws. This, naturally enough, profoundly offended the king's representatives. The case of Don José Hurtado de Mendoza is an example. The twenty-five-year-old was the son and namesake

49 See AGI, Guadalajara, 158. For a similar case see AGI, Guadalajara, 100.

50 AGI, Panama, 196. In another case involving a high-ranking bureaucrat, Mexico's treasury accountant Don Manuel de Cueva was accused of crimes against the state's finances (crímen de hacienda). This case also resulted in asylum proceedings in the 1770s. See AGI, Guadalajara, 402. 
of the Count of Orizaba, a powerful landowner said to be a direct descendant of the last native ruler of Mexico, Emperor Moctezuma, and several Spanish nobles who had rendered valuable services to the Crown of Castile. Accompanied by a group of armed men, young Hurtado released one of his workers, a mestizo cowboy named Antonio de Cáceres, from the jail of the town of Tulancingo in central Mexico. In the process he injured two justice officials and threatened to kill another person.

Cáceres had stabbed to death a lower-class Spanish woman who refused his drunken sexual advances in her home one night in May 1722. The woman's young daughter had witnessed the crime, and one of her elder sons, a tailor's apprentice, had accused Cáceres to the authorities. Four years later, Cáceres was still at large; the victim's offspring found him, declared his whereabouts, and asked royal officials to make sure he was immediately jailed. Defying the noble family's power, a brave alcalde in Tulancingo had the murderer removed from the stables of one of the count's haciendas and sent to the local jail.

Enraged, young Hurtado de Mendoza declared that the cowboy was subject to his noble father's jurisdiction and that royal officials could not interfere in the case. This was why he decided to free Cáceres by force. The crown's disapproval and reaction were, however, swift. The Audiencia and the viceroy sent a large contingent of soldiers to arrest the arrogant nobleman, but he eluded them. Tried in absentia, he was sentenced to ten years in an overseas prison. Several of the workers who had assisted him were sentenced to flogging and either harsh prison terms or forced labor, depending on whether they were white or of color. Led by Hurtado de Mendoza, they all entered local churches and demanded sanctuary.

In early 1727, the count's son was being sheltered at Mexico City's Convent of San Francisco. Meanwhile, as the annoyed viceroy, the Marquis of Casafuerte, reported to the king, the determined count used all his influence to persuade royal authorities to overturn his son's sentence. Not only did he obtain various certificates attesting to his noble background and his family's services to the crown, but he also received letters of support from leading members of the Mexico City municipal council. Furthermore, through his attorney, he asked that his son be covered by one of the royal amnesties typically extended on particular occasions, such as to celebrate a royal wedding. The count offered a generous, two-thousand-peso donation to the royal coffers. It was to be paid, though, only on the condition of first receiving written proof that his son was pardoned.

How the case was resolved is unclear. Regarding the son's church asylum with Mexico City's Franciscans, the records suggest that sanctuary became a major impediment to punishment. Royal officials in Mexico repudiated such outrageous behavior against the crown. ${ }^{51}$ Yet they doubted that the young

\footnotetext{
51 As the Audiencia put it, "este ha sido un hecho grave pues el condenado y su padre han querido que se disumule tan ofensivo atentado, especialmente para que se les mantenga su
} 
noble would ever be punished, given that his powerful father had many "protectors pulling strings," and especially because asylum and the lapse of time would probably diffuse the tense situation. ${ }^{52}$

The church, though, was willing to confront the crown to defend not only high-ranking bureaucrats, landholding aristocrats, and other powerful people but also humbler members of society. This can be illustrated through numerous cases involving common soldiers accused of crimes. Crimes committed by military men appear to have been frequent at the time, and it was also common for the culprits to find shelter in local churches. Typically, tensions between the high clergy and the court-martial-hungry military hierarchy followed.

In one case from 1768, after lengthy disputations two soldiers stationed in Havana were eventually extracted from a local church where they had received sanctuary after each had committed a murder. In Mexico City in 1775, Manuel Castrejón of the local Regimiento de Dragones and an accomplice killed a poor man from whom Castrejón had already stolen a fresh mojarra fish. The victim insulted both soldiers, calling them picaros y ladrones (crooks and thieves); Castrejón caught up with him at a local cemetery where he had run to protect himself. Then, after committing the murder, Castrejón himself sought refuge at the church of San Miguel. This affair unleashed a long series of proceedings in which state representatives and clergy clashed over how to treat the murderer.

In Havana in 1779, soldier Pedro Saeta sought refuge in the Angel Custodio (Guardian Angel) parish church after killing Juan Salcedo, a member of another local regiment. Intense and lengthy asylum proceedings followed. In early 1780, a soldier in the local Regimiento de Infantería de Granada killed one of his peers and sought refuge in one of the churches of Puebla, Mexico. The list goes on; it even includes cases of soldiers who sought sanctuary to avoid court-martial for temporarily abandoning their guard posts. ${ }^{53}$

Confrontations between crown and clergy in these cases reached the point of requiring the regular intervention not only of the highest authorities in the New World, royal audiencias in particular, but even, as in some cases noted here, the highest tribunal in Spain, the Council of the Indies. The historical records are full of these cases. ${ }^{54}$ The records also contain numerous references to other ignoble murderers, thieves, abusive spouses, and people engaged in illicit

respeto en estas distancias" (this has been a grave incident, for the criminal and his father have tried to belittle it, especially so that they continue to enjoy the respect they receive here). See AGI, Mexico, 682.

52 “. . duda que se consiga [castigarlos] porque ahora los delincuentes se hallan refugiados en sagrado y no les faltan protectores esperando acomodarlo todo con el beneficio del tiempo y sus accidentes." AGI, Mexico, 682.

53 These and other cases are addressed in a bulky volume of original documents. See AGI, Indiferente, 3025. See also AGI, Guadalajara, 402.

54 For examples throughout the eighteenth century, see AGI, Panama, 196; AGI, Guadalajara, 100; AGI, Guadalajara, 158, fols. 3-203; AGI, Guadalajara, 402; AGI, Guadalajara, 404; AGI, 
sexual affairs, safeguarded by the clergy even if it resulted in a clash with civil or military authorities. $^{55}$

Occasionally, however, ecclesiastical and military authorities cooperated. In 1758, after numerous incidents involving soldiers under church asylum, the navy commander, Lieutenant General Francisco Caxigal de la Vega, and the bishop of Havana reached a concordia (agreement) for the prompt extraction of military personnel from local churches. ${ }^{56}$ Similar agreements were later reached between the church and royal officials in Mexico City and Guadalajara. Generally, however, royal authorities became impatient with the clergy's zealous stance on asylum, and could not persuade them to be more flexible or careful in determining the crimes covered by the sanctuary privilege. The records suggest that the clergy appeared willing to shelter criminals whose offenses were clearly excluded from sanctuary (groups of bandits, royal officials undergoing residencias, people who had committed crimes inside cemeteries or churches, criminals who had escaped from jail) and did not spare any human or divine resources or chastisements to do so. ${ }^{57}$

If church officials offended the crown and military, the crimes and criminals themselves outraged the secular authorities. Rather than devoting themselves to prayer and contemplation, many criminals under sanctuary seem to have had other occupations in mind, which at various points brought state officials (and some bishops) to the verge of desperation. The picaresque novels suggest some of this behavior; the legal record confirms it. It was the main reason behind the 1758 agreement between the bishop of Havana and the local governor to extract criminals from various churches throughout the city and transfer them to the church of the Fortress of the Florida Presidio at St. Augustine. The criminals constantly got drunk and fought inside the holy places. The refugees had allegedly also assaulted passersby. ${ }^{58}$

\footnotetext{
Mexico, 682; Biblioteca de la Real Academia de Historia, Madrid, Colección Benito de la Mata Linares, 1672, fols. 115-16, 203-371.

55 See, for instance, AGI, Guadalajara, 404; AGI, Guadalajara, 402; AGN, Mexico, Criminal, vol. 2, 33, 112; AGN, Mexico, Californias, vol. 65, cases 6 and 8; Archivo Judicial de Oaxaca, vols. 31 and 32, cases 937 and 951; AGN, Colombia, Criminales, Colonia, vols. 43 (fols. 9961000), vol. 44 (fols. 1-262), vol. 95 (fols. 380-499).

56 AGI, Indiferente, 3025.

${ }^{57}$ Under the law, those who had escaped from jail could not really enjoy asylum. Nevertheless, examples suggest that they did. See AGN, Mexico, Criminal, vol. 2, case 2, fols. 31-69; Archivo Real Chancilleria de Valladolid, box 270, case 2. On the exclusion of these cases, see Miguel Cayetano Sánz, Modo y forma de instruir y substanciar las causas criminales (Madrid: Imprenta de Don Joseph Doblado, 1790), 32-44. Elizondo, among others, also suggested that all parricidas, spousal murderers included, were excluded from asylum, yet in practice they were not. Some contemporary prosecutors shared his opinion. See Elizondo, Práctica universal forense, 1:284; Mexico, AGN, Criminal, 8 , f. $354-55$.

${ }^{58}$ AGI, Indiferente, 3025.
} 
Similar complaints were heard in late colonial Mexico. On finishing his term, Viceroy Carlos Francisco de Croix (1766-1771) left his successor an account of the difficulties he had faced during his tenure. He lamented having found many criminals sheltered in the city's churches, who committed further crimes day and night. They also switched sanctuaries almost at will ("Habia muchos reos, que con insolencia salian de ellos [refugios] de dia y de noche a cometer robos y muertes, y se volvian a dichos refugios, mudandose de uno a otro.") He boasted of unspecified reforms. ${ }^{59}$ Judging by subsequent events, however, those reforms had limited impact. During that same decade, one of the audiencia's fiscales accused the retraidos found in Mexico City's holy places of committing bloody crimes inside the churches and cemeteries and of abandoning their sanctuaries to commit injuries, murders, or thefts in the city streets. The fiscal alleged that this was due partly to their "evil inclinations and extreme poverty" (mala inclinación o suma pobreza). ${ }^{60}$

In some cases, by contrast, the truth seems to be that the criminals were simply annoyed by the authorities' attempts to restrict the comfortable lifestyle they had apparently grown accustomed to. In this regard, two retraidos in the cemetery of the Parish of Santa Catalina, Mexico City, fought with a representative of the crime-specialized Tribunal de la Acordada, accompanied by the parish priest and some of his assistants. This episode occurred shortly after the city's male and female retraidos were segregated and transferred to separate shelters. The delegation had come looking for two "tramps" (mujercillas) the criminals had smuggled into the sanctuary. ${ }^{61}$ The men went after the authorities, killed the Acordada official, injured two of his assistants, and came close to beating up the vicar, too.

A few months later, in 1777, another group of retraidos in the San Miguel parish church hurled stones at some guards patrolling the neighboring one afternoon. They injured one of them, and possibly forced the others to shoot and kill one of the criminals. Another example comes from Guadalajara in 1778, where murder suspect María Potenciana, a mulatta and the only female among a large group of asylum seekers in the cathedral, was eventually transferred to another church and later to the city jail. She was charged with refusing to stay at the new place and returning to the original

\footnotetext{
59 "Memoria que el Virrey Carlos Francisco de Croix dejo a Don Fray Antonio María de Bucareli y Ursua, 1-IX-1771," in Instrucciones y memorias de los virreyes novohispanos (México: Editorial Porrúa, 1991), 2: 954-1008, esp. 960-61.

60 AGI, Guadalajara, 402.

61 On the story and character of this tribunal, see Collin M. MacLachlan, Criminal Justice in Eighteenth-Century Mexico: A Study of the Tribunal of the Acordada (Berkeley: University of California Press, 1974).
} 
sanctuary, causing constant "scandals," mostly at night. ${ }^{62}$ All these cases suggest that outlaws wished to preserve their criminal lives and were ready to fight to do so.

Time apparently was on their side. The crown resented that criminals could stay in churches up to years at a time while their cases remained idle and their lives relaxed. This was because canon law proceedings in matters of asylum (tramite de los artículos de inmunidad) could be terribly sluggish. For example, in the late seventeenth century in the mining center of Mazapil, in northern Mexico, an ecclesiastical judge declared that a woman accused of complicity in the murder of her husband was not to be covered by the asylum laws sixteen months after leaving her place of sanctuary. By this time, however, the woman had died and, according to the archival document, the local chief justice, who had been excommunicated from the outset, continued to live in spiritual agony. ${ }^{63}$ Perhaps hyperbolically, an official report on the matter of sanctuary issued in August 1779 noted that in the recent past some cases of refugees and fugitives had lasted up to twenty years without resolution. ${ }^{64}$ The norm was probably shorter, such as the case of Ignacia de Ontiveros. She had an illicit affair with a married treasury official, and to avoid going to jail she sought refuge in the Guadalajara cathedral. She lived there for more than eighteen months, and even gave birth there. ${ }^{65}$ Another list of prisoners housed in the same cathedral includes people whose cases had been pending for more than two years. Apparently they remained in the holy place the entire time. ${ }^{66}$

Over the long periods that alleged criminals spent in Catholic sanctuaries, ecclesiastical authorities were said to lose track of who had done what. The clergy did not know whether all of the church dwellers had even committed a crime, or whether they were just ociosos y bagamundos (idle vagrants) posing as criminals to receive free food and shelter for long periods, which apparently some did. ${ }^{67}$

The church's own internal procedures in cases involving sanctuary were lengthy. Related judicial disputations between church and crown, especially the so-called recursos de fuerza (equivalent to an appeal to royal tribunals against the ecclesiastical judges' decisions), also could be protracted. ${ }^{68}$ The ecclesiastical authorities appeared anxious to prevail at any cost, and they

\footnotetext{
62 All of these and several other cases are discussed in a bulky volume of criminal and administrative records: AGI, Guadalajara, 402.

63 AGI, Guadalajara, 402.

64 Ibid.

65 AGI, Guadalajara, 404.

66 AGI, Guadalajara, 402.

67 Ibid.

68 For a detailed study of the fuerza procedure in eighteenth-century Spain, representative of some of the practices in the New World, see María Teresa Bouzada Gil, La via de fuerza. La práctica en la Real Audiencia del Reino de Galicia. Siglos XVII - XVIII (Santiago de Compostela: Xunta de Galicia, 2001).
} 
were committed to litigate the cases for as long as it took, for several years if necessary. Apart from any possible material incentive, in cases like those of Manuel de Alderete or José Hurtado de Mendoza, defeating the crown had symbolic value for church authorities. It ratified the magnanimity and humanitarian character that the Catholic Church always strove to project. More important, it demonstrated that the clergy were as powerful as high-ranking state officials. They could, for example, make use of the frightening sanctions of excommunication to block the government's actions. It also served to illustrate that divine justice was mightier than human justice. These benefits apparently justified any possible overindulgence by exceedingly zealous members of the church.

A factor that worsened the consequences of the protracted legal procedures was that the sanctuaries became overcrowded, which concerned everyone. One of the best examples comes from Guadalajara, the second-largest urban center in colonial Mexico. In February 1778, in the city's cathedral alone, no fewer than eighteen retraidos were living together. The group was a peculiar mix, an extraordinarily interesting example of local society and the criminal universe. All but one was male, and they included representatives from all ethnoracial categories: at least four "Spaniards" (that is, whites), three coyotes, two mulattos, one pardo (brown or mulatto), one Indian, one foreigner (French), and six others whose ethnicity, as sometimes occurs in the documents, mainly with mestizos, was not revealed. Seven were accused of homicide, two of theft, and two others of illicit affairs with married women. One was a debtor. The rest of their crimes were not specified, in one case because the refugee probably was not a criminal at all but, as he himself put it, was in the sanctuary because le conviene (it was convenient to him).

Equivalent conditions certainly obtained in Mexico City. Indeed, fiscal Diego Acosta, one of Guadalajara's crown attorneys, had gone to do some work in Mexico City and learned that many criminals had recently been extracted from the capital's overcrowded churches and cathedral.

Up to about early 1778, large groups of men and women reportedly lived together in Mexico City's churches and cemeteries for long periods and, as noted, brought boyfriends, girlfriends, and prostitutes in for nights of partying, drinking, and card playing. Their group life was even allegedly linked to their supposed recidivist inclinations, because, as the Mexico City fiscal put it, if a single person has evil inclinations, "what could be expected from a group of crooks? What could be their learning and plans, the lessons they teach each other, the motivation they draw from one another?"69 Capital officials tackled this critical situation by segregating males and females, planning to house them in separate sanctuaries. At the same time, they decided to transfer

\footnotetext{
69 “Que hará una junta de tantos perbersos [sic]? Cual será su estudio y sus maquinaciones, las lecciones que mutuamente se den, el aliento que se infundan?” AGI, Guadalajara, 402.
} 
to local jails those who apparently did not qualify for asylum until their cases were finally decided, and to expel from the sanctuary those whose cases might not have sufficient merit, debtors in particular. ${ }^{70}$

Encouraged by the news, fiscal Acosta set out to request a similar procedure for Guadalajara, for which he compiled reports from ecclesiastical authorities and local justice officials about the ongoing asylum cases and the people currently living in local churches. In any event, the situations of colonial Guadalajara and Mexico City presumably were duplicated in other urban centers; the historical records contain references to incidents in colonial Buenos Aires, Chile, Colombia, Guatemala, Panama, Peru, and the Philippines. ${ }^{71}$

\section{ATTEMPTS AT REFORM}

The excommunications of officials and the suspension of masses for entire localities, prolonged proceedings, scandalous behavior of criminals, and overcrowding all persisted despite the several Papal bulls and briefs (breves) and the half-dozen or so royal cédulas (decrees) enacted in the eighteenth century to regulate and moderate asylum. Four different popes during that period issued canonical decrees that addressed various aspects of the issue. Some of these measures excluded from asylum all cases of voluntary homicide, forgery of ecclesiastical documents, and money forgery; others limited the number of churches where criminals could seek refuge, excluding rural churches and hermitages (ermitas) in remote and deserted locations, as well as the exterior walls of church buildings, most residences of priests, private chapels, and bell towers detached from a church. Others agreed to the sanctioning of one or, at most, two churches in each major urban center as the only possible places for criminals to shelter. $^{72}$

The Papacy, or Holy See (Santa Sede), and the Spanish Crown had also signed a concordato, or covenant, on 26 September 1737, which affected sanctuary. Several articles confirmed that any crime on public roads involving deaths or bodily mutilation would be excluded from asylum. So would crimes of conspiracy against the crown. The concordato ruled out the possibility of ecclesiastical immunity in rural churches and ermitas and also rejected

70 Baltasar Ladrón de Guevara, fiscal of Mexico's Real Audiencia, and the Mexican bishop both reported these and other solutions in January and March 1778. The measures were embraced the following month. See AGI, Guadalajara, 402.

71 AGI, Indiferente, 3025.

72 The long list of papal decrees includes Benedict XIII, "Ex quo divina," 8 June, 1725; Clement XII, “In suprema justitice," 29 Ene., 1734; Benedict XIV, “Officii nostri ratio,” 15 Mar. 1750; and, Clement XIV, “Ad perpetuam rei memoriam," 12 Sept. 1772. Copies of some can be found in AGI, Indiferente, 3025; Biblioteca de la Real Academia de Historia, Madrid, Colección Benito de la Mata Linares, 1761, fols. 607-17. There are also references to asylum-related measures enacted by, among others, the Cuban Synod (i.e., Constitution 7, tit. 14, book 3), and the 4 Concilio Provincial Mexicano (Book 3, title 22). See AGI, Indiferente, 3025; and, titles 5 and 9, libro 1, Recopilación de las Leyes de Indias. 
the so-called cold-church asylum (asilo en iglesias frias), which referred to criminals' falsely asserting that they had been removed from a church and demanding to be sent back there. This seemingly common maneuver gained many unjustified concessions of sanctuary. ${ }^{73}$

Even after the concordato, the crown enacted royal decrees to clarify and expedite the procedure for secular judges to extract criminals from their places of asylum (sagrados). The various royal orders stipulated that to extract criminals as promptly as possible, secular judges should observe the requirement to offer guarantee or promise that the individuals removed from religious asylum would not be "offended" (caución juratoria de no ofender). This meant that the accused would not be subject to the death penalty or any corporal punishment, mutilation in particular. The decrees also specified the legal recourses justice officials could invoke to protest and contain abuses (fuerzas) by ecclesiastical authorities. ${ }^{74}$ Besides such general rules, ad hoc measures were also issued to resolve critical cases, such as the ones in Mexico City in early 1778. Similar measures were also being considered for Guadalajara, and later were adopted everywhere in the Spanish realms. ${ }^{75}$

In November 1800, the crown issued a cédula extending to all its domains the Mexico-modeled policies on asylum, which had been implemented in all the American possessions after 1787 and reemphasized in an additional 1797 royal decree. Under those policies, extraction of criminals from churches would be prompt, criminal investigations would be expedient, and jurisdictional controversies between ecclesiastical and secular judges would be decided swiftly under a procedure spelled out in great detail. The royal decree upheld the longstanding practice concerning punishment: that criminals eventually covered by asylum could not be sentenced to more than ten-year presidio terms, labor, public service, or destierro (banishment). ${ }^{76}$ Yet one more cédula was issued in March 1807 that required secular judges to give oral rather than written notification to priests before the imminent extraction of criminals from churches. While maintaining the promise of saving criminals' lives and physical integrity ("de no ofenderle su vida y sus miembros"), this

73 See laws 4 and 5, title 4, book 1, Novisima Recopilación, in Códigos españoles, 7: 18-19.

74 See royal cédulas issued in Oct. 1750, Apr. 1764, July 1768, Oct. 1770, Nov. 1773, and Mar. 1787. AGI, Indiferente, 3025; AGI, Guadalajara, 402; AGI, Guadalajara, 403. See also AGI, Filipinas, 335, L. 17, 2, 60-63, and various other royal decrees concerning asylum for soldiers and the military. Laws 7 to 11, title 4, book 1, Novísima Recopilación, in Códigos españoles, 7: 22-24.

75 See AGI, Guadalajara, 402.

76 See Royal Cédula issued in San Lorenzo on 11 Nov. 1800, in law 6, title 4, book 1, Novísima Recopilación, in Códigos Españoles, 7: 21-22. For the 1787 regulations, and the 1797 reminder, see Biblioteca de la Real Academia de Historia, Madrid, Coleccción Benito de la Mata Linares, 1768, fols. 353-56; ibid., 1773, fols. 394-99. 
measure was aimed once more at expediting their removal and impeding them from escaping their refuge. ${ }^{77}$

\section{A LINGERING REALITY}

After several late eighteenth- and early nineteenth-century reforms, additional legal manuals continued to address the controversial institution of sanctuary. Joseph Marcos Gutiérrez, Juan Alvarez Posadilla, Miguel Cayetano Sanz, and Francisco Elizondo, to name but a few, were among the best-known authors and magistrates commenting on asylum in their widely read texts on criminal law and procedures. Commenting in 1789 on the classical work of sixteenth-century jurist Antonio Gómez, Gutiérrez listed the crimes that the contemporary canon and royal law excluded from asylum. ${ }^{78}$ So did Alvarez Posadilla, a fiscal in one of Spain's audiencias in the early nineteenth century, in his treatise on criminal law. He endorsed the late eighteenth-century papal bulls that mandated only one or two churches in a village as designated sanctuaries. He also provided a comprehensive list of all of the crimes excluded from asylum and the detailed procedure for extracting criminals from sacred places. $^{79}$

For Cayetano Sanz, legal writer and relator del crimen in Spain's Chancilleria de Valladolid, the most controversial issue was whether secular judges needed ecclesiastical authorization to extract criminals whose crimes were excluded from asylum protection. Basing his opinion on the most recent papal bulls and numerous classical legal authors, he contended that ecclesiastical orders were indispensable. ${ }^{80}$

77 See Royal Cédula issued in Aranjuéz on 13 Mar. 1807, in Real Academia de Historia, Madrid, Coleccción Benito de la Mata Linares, 1768, fols. 353-56; ibid., 1777, fols. 277-79.

78 Joseph Marcos Gutiérrez, Compendio de las varias resoluciones de Antonio Gómez en que se contiene todo lo sustancial de estas y se ponen muchas notas de las mas útiles e importantes de Atillón y Suárez (Madrid, 1789), ch. X, 69-70.

79 The list included: "los que cometen los ladrones públicos, salteadores de caminos, los que talan los campos, los que cometieren homicidios o mutilaciones de miembros en las Iglesias o sus cementerios, y los que hicieren alguna muerte a traición, los asesinos, los reos de heregia o lesa Magestad, los que cometieren el homicidio de caso pensado o deliberado, los falsificadores de letras apostólicas, los superiores y empleados en los Montes de Piedad u otros fondos públicos o Bancos, que cometieren hurtos o falsedad, los monederos falsos, o los que cercenan moneda de oro o plata, los que fingiendose Ministros de Justicia se entran en casas ajenas y cometen en ella robos con muerte o mutilación de miembro, los que conspiran contra los Reynos con contra el estado, el fallido y alzado en sus bienes, pero no el que sin alzarse se acoge; los que hubiesen contribuido al homicidio alevoso con mandato o consejo, inducción, auxilio cooperativo, $u$ otro favor y ayuda, aunque sean menores de 25 años, como sean mayores de 20, los indiciados y procesados, o en rebeldía llamados por edictos y pregones, y condenados por causa de homicidio, aunque sea hecho en pendencia con armas, o instrumentos proporcionados por su naturaleza para matar, como no sea el homicidio casual o en propia defensa." See Juan Alvarez Posadilla, Práctica Criminal por Principios o Modo y Forma de Instruir los Procesos Criminales de las Causas de Oficio de Justicia contra los abusos introducidos, 3 vols. (Madrid: En la Imprenta que fué de García, 1815), 1: 307.

${ }^{80}$ Sánz, Modo y forma de instruir y sustanciar las causas criminales, 32-45. 
Elizondo, fiscal in Spain's Chancilleria de Granada, whose views on asylum have already been noted, took a narrower approach. In the sixth edition of his law manual, he declared that only the vicar general of a bishopric could authorize a royal justice official to extract criminals. Such extraction required that the judge offer a guarantee (caución) that the asylum seeker's life and physical integrity would be protected. Should the ecclesiastical authorities, on reviewing the case, issue an order stating that the accused had a valid claim to asylum (carta de restitución), the person would be immediately restored to the church designated by the vicar. In case secular judges disagreed with the ecclesiastical decision, they could present a petition (recurso de fuerza) to the nearest royal audiencia or chancilleria arguing that said criminals were excluded from asylum rights and therefore should remain in a secular jail. If they refused to obey ecclesiastical orders immediately, justice officials risked excommunication. Elizondo therefore suggested that they could also ask higher courts to protect or absolve them from such severe ecclesiastical punishment or other forms of religious censure (censura), against either them or their villages. ${ }^{81}$ Overall, things did not appear to have changed dramatically in more than a century.

Legal reforms notwithstanding, the procedures Elizondo and others discussed continued to be terribly formalistic and protracted. Likewise, the disputes between justice officials and clergy over asylum remained intense and acrimonious. Meanwhile, individual culprits - including some whose crimes were, in principle, excluded from asylum - could do as they pleased: run away, sabotage the investigation, or simply fade into oblivion. They definitely were confident, and they eagerly proclaimed that they would receive no death sentence or other form of bodily punishment.

\section{ONCLUSIONS}

The picture of church sanctuary in the Iberian world fits poorly with the institution's longer-term record in other Western Christian nations. Arguing that its widespread abuses must be controlled, the English, from the fourteenth century on, debated the need to restrict the use of churches as asylums for criminals. At last, under Henry VIII, as a result of a strong anticlerical wave and a systematic attempt to destroy all jurisdictions rivaling the power of the king, significant restrictions regarding sanctuary appeared. First, an increasing number of crimes were exempted from the benefit (treason in 1534; all serious felonies in 1540). Second, in the early 1530s the abjuration of the realm was limited. Finally, in 1540 all sanctuaries except churches and churchyards were abolished. ${ }^{82}$ Though debates continue on the matter, some historians have argued

81 Elizondo, Práctica universal forense, 1: 284-89. For examples of desperate requests in this sense see AGI, Guadalajara, 100.

82 Thornley, "Destruction of Sanctuary," passim; Trenholme, "Right of Sanctuary in England," 30-31, 59-60; Timbal-Duclaux de Martin, Le droit d'asile, 355-56, 431-32, 437. 
that the institution of sanctuary itself was "abolished as a general matter. . . [in] the 1620 s." 83

Still, sanctuary proved hard to eradicate completely, being revived by subsequent English monarchs and also subsisting de facto as a deeply rooted custom even after its formal abolitions. Hence, in 1697, the Parliament decreed once more that "every so-called sanctuary was suppressed and sanctuary ceased to exist in England," even as some isolated instances suggest that as late as the nineteenth century the practice persisted. ${ }^{84}$ One of its most enduring modalities was that of sheltering debtors. ${ }^{85}$ Nevertheless, it seems evident that after the early seventeenth century church asylum was considerably weakened, and ceased to be a prevalent or widespread institution or practice in England. It is interesting that it was not just in this most Protestant of nations but also in deeply Catholic nations like France that church asylum fell under early attack. Indeed, France was the first Catholic country where asylum was seriously challenged. This took place, as in England, in the early sixteenth century. According to some authors, by 1539 some regions had entirely done away with it. By the seventeenth century, religious asylum had lost importance in all but a few French provinces. ${ }^{86}$

Undoubtedly, any remnants of the institution, whether in England, France, or elsewhere, paled when compared to the tenacity of sanctuary in Iberia and its American dominions. ${ }^{87}$ There, even amid scandalous practices by clergy and criminals alike, and despite numerous ecclesiastical and civil measures to regulate it, sanctuary continued to enjoy widespread acceptance well into the nineteenth century.

Further research is required to understand the circumstances and timing of sanctuary's ultimate demise, which probably occurred only in the postindependence era after the 1820 s and perhaps under the influence of liberal reformers. For the present, the longevity of asylum appears to symbolize how fundamentally the Spanish Catholic Church remained central not only to education, taxation, and record keeping but clearly also to the administration of justice even in matters far beyond crimes against the faith or the clergy. The church had a say in the punishment, or lack thereof, of all sorts of individuals

83 In 1624, under King James I, Parliament enacted a rule that sanctuary could not be allowed in any case. See Helmholz, "Law of Sanctuary," 20. For conflicting views, see William C. Ryan, "The Historical Case for the Right of Sanctuary," Journal of Church and State 29 (1987): 209-32, esp. 229.

84 Trenholme, "Right of Sanctuary in England," 31.

85 Ryan, "Historical Case for the Right to Sanctuary," 229; Stirk, "Arresting Ambiguity," passim.

86 Le Bras, “Asyle," 1044-45.

87 An authoritative work claims that asylum was abolished in Silesia in 1743, Tuscany in 1769, Prussia in 1794, most German states early in the nineteenth century, and Italy in 1850. Le Bras, “Asyle," 1046; Timbal-Duclaux de Martin, Le droit d'asile, 450-51. 
accused of virtually any crime, from murder, spouse battering, and theft, to embezzlement of public funds or a military sentinel's dereliction of duty.

At the same time, the lingering presence of asylum was a definite advantage for the common folk. Not only did they use it to avoid punishment, they maintained an insolently libertarian lifestyle at the same time, not the least aspect of which was a creative capacity to fake crime for the sake of free food and shelter. 